\title{
Adaptation strategy of different cow genotypes to the voluntary milking system
}

\author{
O.O. Borshch ${ }^{1}$, B.V. Gutyj ${ }^{2 *}$, O.I. Sobolev ${ }^{1}$, O.V. Borshch ${ }^{1}$, S.Yu. Ruban ${ }^{3}$, V.V. Bilkevich ${ }^{1}$, \\ V.R. Dutka ${ }^{2}$, O.M. Chernenko ${ }^{4}$, M.M. Zhelavskyi ${ }^{5}$, T. Nahirniak ${ }^{2}$ \\ ${ }^{1}$ Bila Tserkva National Agrarian University, Bila Tserkva, Ukraine
${ }^{2}$ Stepan Gzhytskyi National University of Veterinary Medicine and Biotechnology, Lviv, Ukraine \\ ${ }^{3}$ National University of Life and Environmental Science of Ukraine, Kyiv, Ukraine \\ ${ }^{4}$ Dnipro State Agrarian and Economic University, Dnipro, Ukraine \\ ${ }^{5}$ State Agrarian and Engineering University in Podilya, Kamianets-Podilskyi, Ukraine
}

*Corresponding author E-mail: $\underline{\text { bvh@ukr.net }}$

\section{Received: 19.12.2019. Accepted 12.02.2020}

\begin{abstract}
The aim was of this study was to discover the adaptation indicators of different breeds first-calving cows to voluntary (robotic) milking system during the first month of lactation. The research was carried out in a robotic farm on German Holstein, French Holstein breeds and Brown Swiss breed of cows. During the adaptation period, the German Holsteins were differed from the rench Holsteins and Brown Swiss breed by milk yield, multiplicity of milking, and the amount of consumed concentrated feed. On the $30^{\text {th }}$ day (end of adaptation period), the German Holstein breed dominated over the French Holstein breed and Brown Swiss having average daily milk yield by 0.73 and $4.12 \mathrm{~kg}$, milking times by 0.26 and 0.34 , the amount of consumed concentrated feed by 0.32 and $0.61 \mathrm{~kg}$ higher. In addition, the German Holstein breed during the adaptation period was distinguished by higher multiplicity of passages through the selection gate and the number of visits to feed stations. Important indicators of adaptation to free keeping and voluntary milking are the number of cases of forced milking. On the $5^{\text {th }}$ day of lactation, some $69.4-86.2 \%$ of cows of all the groups did not enter the milking robot. This indicator has been steadily declining every five days. On the $30^{\text {th }}$ day of lactation the cases of operator-forced milking were $24.3-35.9 \%$ and they were the lowest in cows of the German Holstein breed, indicating the best adaptive qualities of this cattle. The German Holstein breed had more lower (by 0.30 and $0.26 \mathrm{mS} / \mathrm{cm}$ ) electrical milk conductivity on the $30^{\text {th }}$ day compared with French and Brown Swiss breeds. In addition, the number of somatic cells in its milk was lower by 19.4 and 17.1 thousand cells per $\mathrm{cm}^{3}$ compared with French Holstein and Brown Swiss breed. Therefore, we suggested that the German Holstein breed has more higher stress tolerance, and hence a shorter adaptation time to the keeping.
\end{abstract}

Key words: Robotic milking; Cow breeds; Adaptation; Productivity; Milking multiplicity; Milk electrical conductivity

\section{Introduction}

Production of cheap high-quality livestock products is possible only with the introduction of modern efficient technologies based on the complex mechanization and automation of processes and operations. In developed countries, livestock production is a highly profitable business, which is based on the maximum implementation of the latest technological developments in the production process (Borshch et al., 2017; Borshch et al., 2018; Hollowey \& Bear, 2019). Such implementations are most effective in large farms. The analysis of world trends in dairy cattle breeding shows the transition of agricultural enterprises to technology with unassisted livestock keeping and the automated processes and operations (Rousing et al., 2006; Drach et al., 2017). Nowadays, developed countries of the world intensively introduce robotic milking systems of cows with various technical support for automated preparatory and final operations like connection and switching of milking cups (Munksgaard et al., 2011; Hansen, 2015; Bach \& Cabrera, 2017). An important feature of automated milking systems is the ability for each cow to independently determine for itself and realize the time and multiplicity of milking, which promotes the creation in animals a certain stereotype of behavioral reactions throughout the day and in turn helps to maintain health and increase milk productivity (Shoshani \& Chaffer, 2001; Jacobs \& Siegfort, 2012; Sitkovska et al., 2015). Robot for milking is installed on farms with stall housing and a population of at least 50 cows (Holloway et al., 2014). The use of robots enables farm workers to devote a major part of their working time to herd management on the basis of data analysis, recorded by the robot. The adaptation of cows to keeping conditions, along with the technological characteristics of a particular farm, also depends on the genetic features that are expressed in duration of adaptation to the new environment conditions (Taylor et al., 2004; Perez-Ramires et al., 2009; Gutyj et al., 2017; Faly et al., 2017; Kozak \& Brygadyrenko, 2018; Bomko et al., 2018; Slivinska et al., 2018; 2019).

The purpose of our research was to study the adaptation peculiarities of the first-calving cows of different breeds to the conditions of robotic voluntary milking. 


\section{Material and Methods}

The research was conducted in robotic dairy farm, Pochuiky village, Popilnia district, Zhytomyr region, Ukraine (4956'37"N, $29 ' 36 ' 28 " E)$. All cows were kept in loose housing in a low cost housing facility $(150 \times 40 \times 10$ m) divided into four sections, each with two milking robots (VMS, DeLaval Voluntary Milking System, DeLaval International AB, Sweden). The scheme of the section is shown in Figure 1.

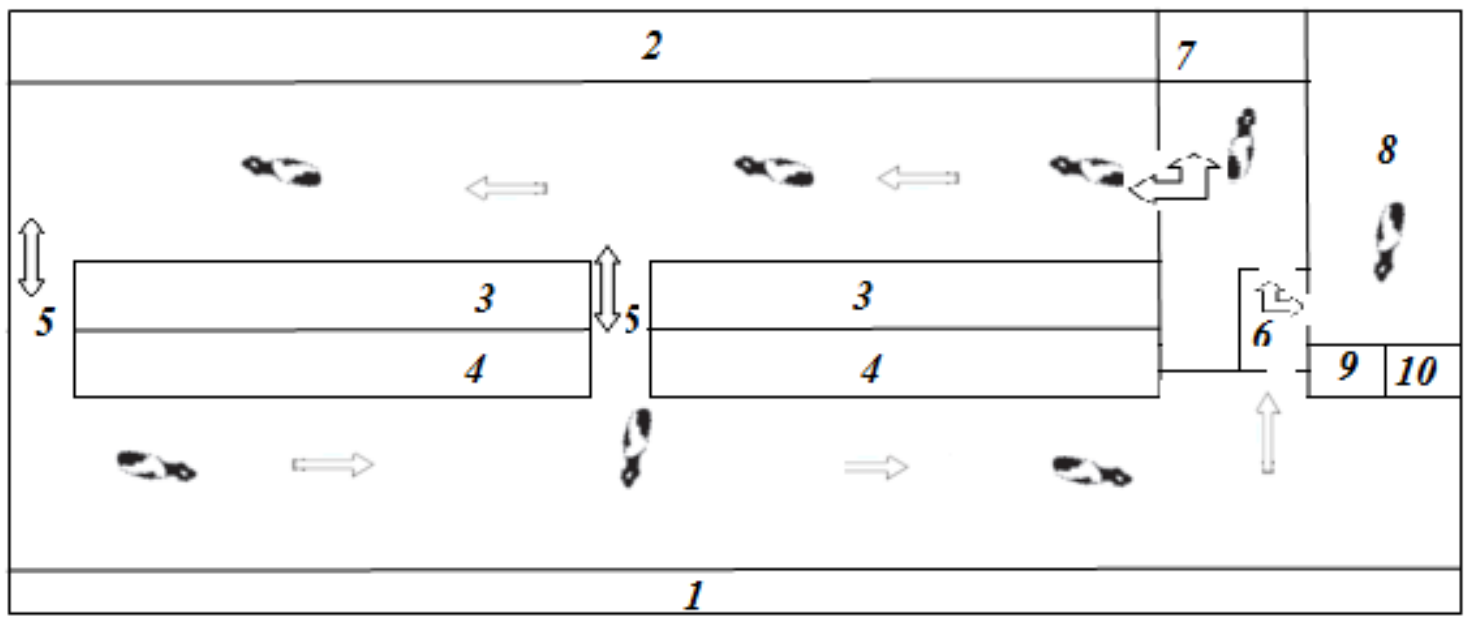

Figure 1. Robotic farm section (1 - feeding bunk; 2, 3, 4 - rows of cow boxes; 5 - passages between rows of boxes; 6 selection gate; 7 - feed stations; 8 - waiting area before milking; 9, 10 - milking robots No 1 and 2).

The farm uses the same year-round feeding of cows with feed mix and with adding concentrated feed during milking and in feed stations. The feeding level is sufficient: animals consume daily $21.4-21.8 \mathrm{~kg}$ of dry matter, the energy value of the consumed feed is $211-220 \mathrm{MJ}$, the energy concentration in $1 \mathrm{~kg}$ of dry matter is $10.3-10.4 \mathrm{MJ}$. Material of the research were the first-calving cows of the German Holstein breed $(n=44)$ and French Holstein breed $(n=31)$, as well as Brown Swiss breed $(n=22)$. The research was carried out during 30 days from the moment when animals were transferred to the farm. Indicators of milking duration and multiplicity, eating at the feeding station and during milking, productivity, number of passes through the selection gates, the milk electrical conductivity and the somatic cells content in it were determined by the DelPro ${ }^{\mathrm{TM}}$ herd management program (DeLaval International $A B$, Sweden). Cases of forced cows' milking are based on the results of daily observations.

Indicators of fat, protein, lactose content in milk were determined in a milk analyzer (Milkotester Lactomat Rapid S, Bulgaria).

The net energy content (NEL) of milk was estimated by means of the following equation, derived from that proposed by the NRC (2001):

$$
\operatorname{NEL}(\text { Mcal } / \mathrm{kg})=0.0929 \times \text { fat }, \%+0.0547 \times \text { protein, } \%+0.0395 \times \text { lactose }, \% \text {, }
$$

where NEL is the gross energy of one $\mathrm{kg}$ of milk.

The NEL values obtained were converted to $\mathrm{MJ} \mathrm{kg}{ }^{-1}$. The obtained data were statistically processed using Statistica 11.0 software. The Student's $t$-test was used to estimate the statistical significance of the obtained values. We considered our data were marginally significant, significant, and highly significant as $\mathrm{P}<0.05,0.01$, and 0.001 .

\section{Results and Discussion}

One of the main indicators that characterizes the adaptive capacity of cows is their productivity. During the 30-day period there were indicated differences in different groups of cows by productivity indicators. The lactation curves of the German Holstein and French Holstein breeds from the beginning of milking in the conditions of robotic milking were marked by stability and evenness (Figure 2). Thus, the difference between the productivity of German Holstein selection in the period from the $5^{\text {th }}$ to the $30^{\text {th }}$ day was $3.32 \mathrm{~kg}$, and the French one $-4.94 \mathrm{~kg}$. In the case of Brown Swiss breed cows, they were characterized by somewhat lower adaptation to the conditions of voluntary milking, and their productivity gradually increased from 17.31 to $24.90 \mathrm{~kg}$ during the month.

Along with the productive signs for the adaptation of dairy cows to the new conditions of keeping and milking the indicators of the quality composition of milk take place. Fat and protein content is crucial, because these components affect the energy value of milk and form its selling price. It has been found that the indicators of fat, protein, lactose content and, as a consequence, the energy value of $1 \mathrm{~kg}$ of milk gradually increased at cows of all groups during the month period (Table 1). The highest average values of fat, protein and lactose during the first month of lactation were observed at Brown Swiss cows: 3.92; 3.41 and $4.43 \%$ respectively. The average energy value of $1 \mathrm{~kg}$ of Brown Swiss cows' milk during the first month of lactation was 3.037 MJ, which is 0.094 and 0.105 MJ more than the similar indicators in the German and French Holstein, respectively.

Our studies are partially agreed with Brazilian researchers who indicate a gradual increase in fat and protein content of Holstein cows at robotic farms (Córdova et al., 2018).

The milking multiplicity indicator in the first months of lactation is an important indicator for not only adaptation to new conditions, but also for further productivity of cows (Melin et al., 2007). Among the cows of different origins, the most varied was the milking multiplicity curve of German Holstein breed (Figure 3), which showed gradual increase in the milking multiplicity from 2.27 on the $5^{\text {th }}$ day to 3.61 times in 30 days after the transfer to voluntary milking conditions. The curve of milking multiplicity of French Holstein selection was slightly different, with a gradual increase from 2.32 times on the fifth day to 3.03 times on the $15^{\text {th }}$ day and keeping its level until the twentieth day. Subsequently, the milking multiplicity slightly increased - up to 3.32 times (on the $25^{\text {th }}$ day) and was at this level by the end of the month. The milking multiplicity of Brown Swiss breed was gradually increasing from 2.28 times on the fifth day to 3.27 times in the $30^{\text {th }}$ day. 


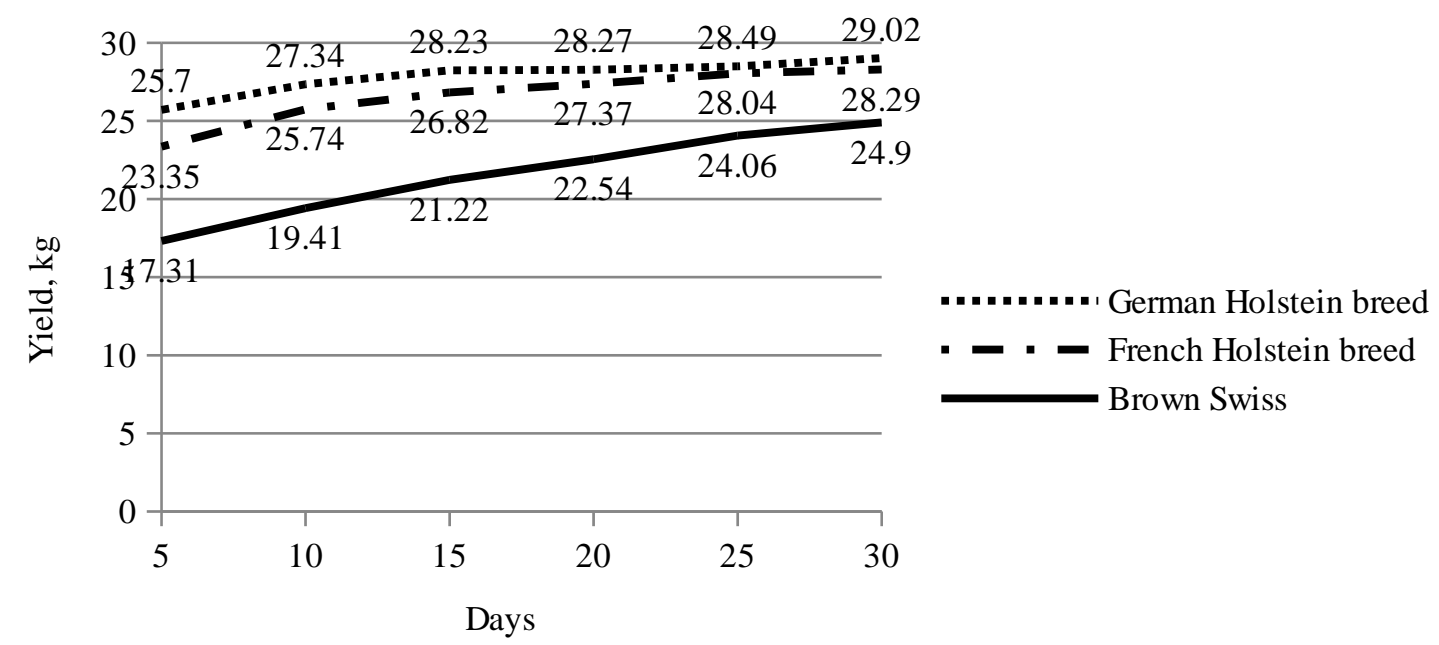

Figure 2. Dynamics of daily milk yield of different genotypes cows.

Table 1. Composition and energy value of $1 \mathrm{~kg}$ of milk during the adaptation period.

\begin{tabular}{|c|c|c|c|c|}
\hline Day & Mass fraction of fat, $\%$ & $\begin{array}{c}\text { Mass fraction of protein, } \\
\% \\
\text { German Holstein }\end{array}$ & $\begin{array}{l}\text { Mass fraction of } \\
\text { lactose, } \%\end{array}$ & $\begin{array}{c}\text { Energy value of } 1 \\
\text { kg of milk, MJ }\end{array}$ \\
\hline 5 & $3.71 \pm 0.02$ & $3.29 \pm 0.04$ & $4.37 \pm 0.04$ & 2.918 \\
\hline 10 & $3.73 \pm 0.02$ & $3.29 \pm 0.05$ & $4.43 \pm 0.03$ & 2.926 \\
\hline 15 & $3.72 \pm 0.04$ & $3.32 \pm 0.05$ & $4.42 \pm 0.04$ & 2.939 \\
\hline 20 & $3.74 \pm 0.03$ & $3.33 \pm 0.04$ & $4.46 \pm 0.04$ & 2.951 \\
\hline 25 & $3.74 \pm 0.02$ & $3.35 \pm 0.03$ & $4.45 \pm 0.02$ & 2.960 \\
\hline 30 & $3.76 \pm 0.03$ & $3.35 \pm 0.03$ & $4.46 \pm 0.02^{\# \#}$ & 2.968 \\
\hline \multicolumn{5}{|c|}{ French Holstein } \\
\hline 5 & $3.68 \pm 0.03$ & $3.32 \pm 0.02$ & $4.34 \pm 0.04$ & 2.905 \\
\hline 10 & $3.69 \pm 0.04$ & $3.33 \pm 0.02$ & $4.38 \pm 0.05$ & 2.922 \\
\hline 15 & $3.69 \pm 0.04$ & $3.32 \pm 0.03$ & $4.37 \pm 0.04$ & 2.918 \\
\hline 20 & $3.71 \pm 0.03$ & $3.34 \pm 0.03$ & $4.42 \pm 0.04$ & 2.939 \\
\hline 25 & $3.73 \pm 0.03$ & $3.36 \pm 0.02$ & $4.42 \pm 0.05$ & 2.951 \\
\hline 30 & $3.74 \pm 0.03$ & $3.37 \pm 0.03$ & $4.45 \pm 0.03^{\# \#}$ & 2.960 \\
\hline \multicolumn{5}{|c|}{ Brown Swiss } \\
\hline 5 & $3.87 \pm 0.02$ & $3.40 \pm 0.04$ & $4.40 \pm 0.03$ & 3.010 \\
\hline 10 & $3.92 \pm 0.03$ & $3.39 \pm 0.04$ & $4.42 \pm 0.02$ & 3.031 \\
\hline 15 & $3.93 \pm 0.03$ & $3.40 \pm 0.05$ & $4.42 \pm 0.02$ & 3.035 \\
\hline 20 & $3.92 \pm 0.04$ & $3.42 \pm 0.04$ & $4.46 \pm 0.03$ & 3.035 \\
\hline 25 & $3.94 \pm 0.04$ & $3.42 \pm 0.04$ & $4.46 \pm 0.03$ & 3.052 \\
\hline 30 & $3.95 \pm 0.03^{\# \#}$ & $3.43 \pm 0.05$ & $4.47 \pm 0.02$ & 3.060 \\
\hline
\end{tabular}

Notes: ${ }^{\# \#} \mathrm{P}<0.05$ as compared to the first period (five days)

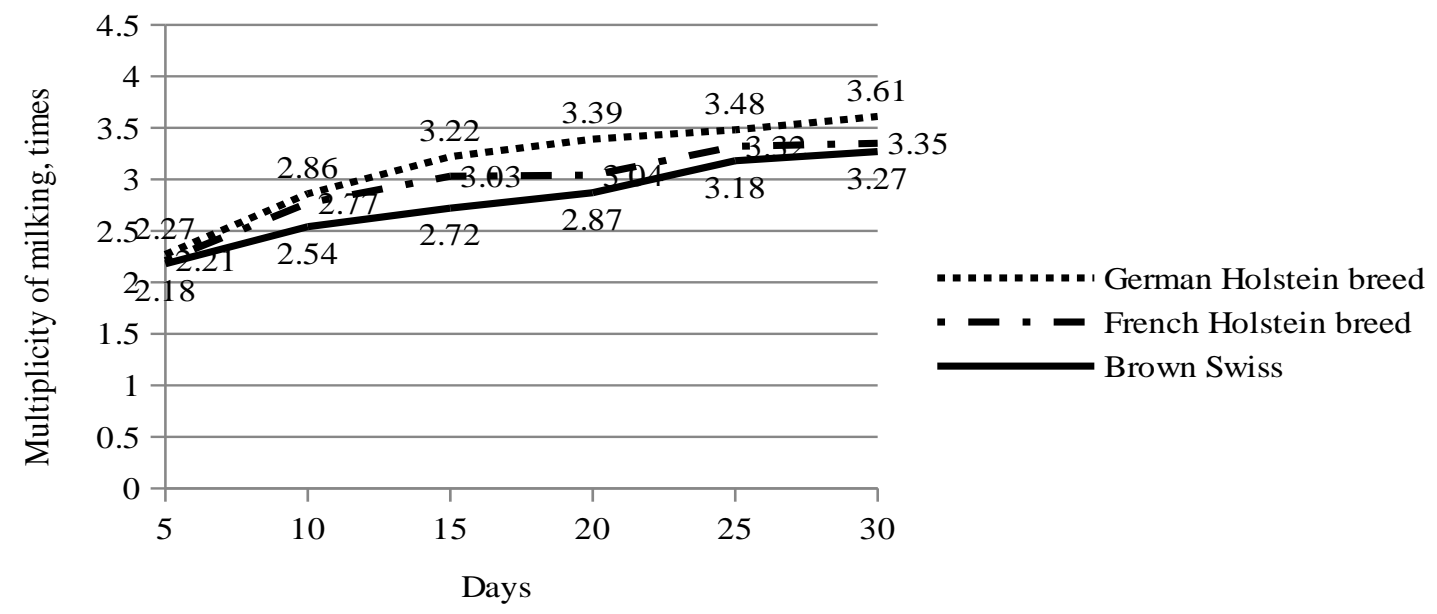

Figure 3. Milking multiplicity of different genotypes cows. 
The rate of concentrated feed consumption is directly proportional to the milking multiplicity and cow productivity. Among the cows of different genotypes during the adaptation period, the highest consumption of concentrated feed was recorded in German Holstein breed. Increased consumption of concentrated feed was gradual from $2.14 \mathrm{~kg}$ for the $5^{\text {th }}$ day to $3.54 \mathrm{~kg}$ for the $30^{\text {th }}$ day (Figure 4 ). The French Holstein breed and the Brown Swiss breed in the adaptation period consumed slightly smaller amount of concentrated feed from 1.90 to $3.22 \mathrm{~kg}$ and from 1.18 to $2.23 \mathrm{~kg}$, respectively.

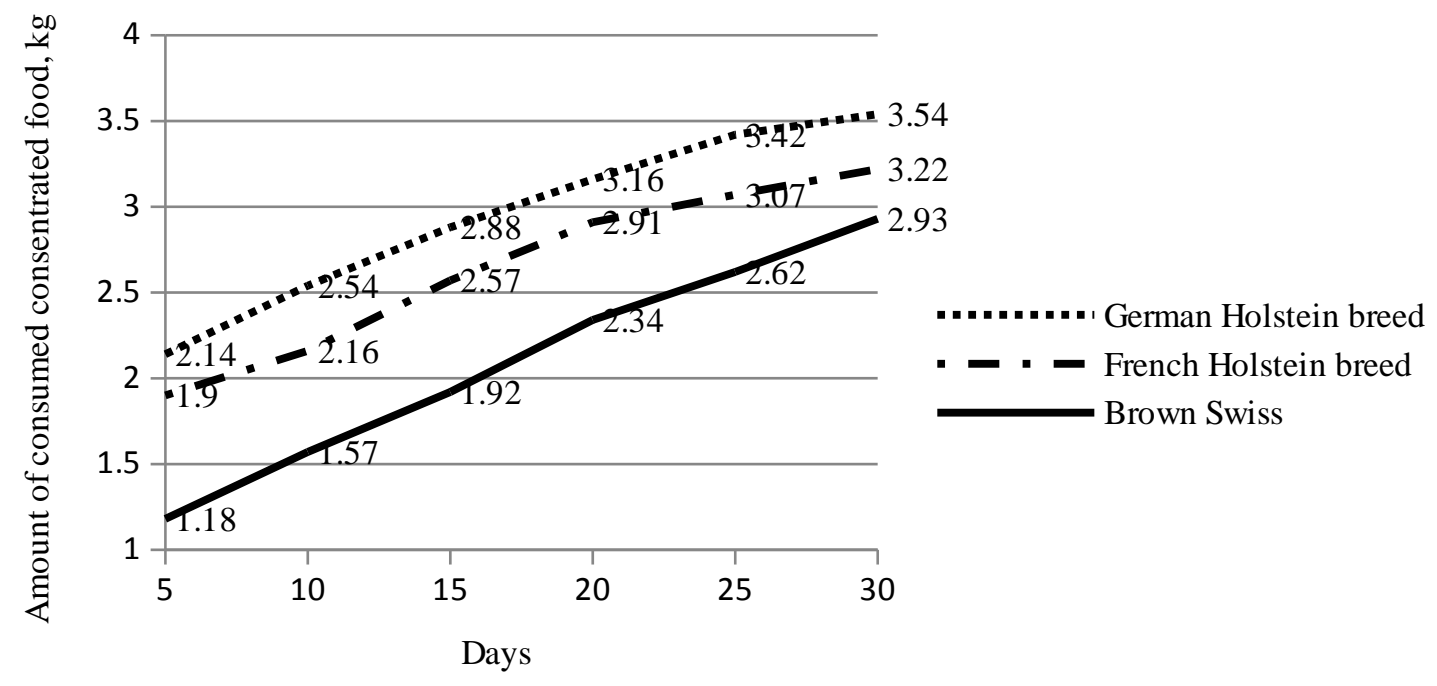

Figure 4. Concentrated feed consumption at feed stations of different cow genotypes.

Important adaptation indicators to free keeping and voluntary milking are the number of passes through selection gates and visits to feed stations, as well as cases of forced milking. These indicators are closely related to the productivity of animals, their ranking in herd and temperament. It was established that in cows of all groups the number of passes through selection gates and visits to feed stations increased during the first month of lactation (Table 2). The greatest values of these indicators during the adaptation period were observed in the group of German Holstein breed: 5.18-6.64 and 2.07-3.52 times respectively. Somewhat lower rates were observed in the groups of French Holstein breed and Brown Swiss breed, which is actually confirmed by the lower daily average milk yields of these cows' groups during the adaptation period. On the $5^{\text {th }}$ day of lactation $69.4-86.2 \%$ of cows of all groups did not enter the milking robot. Every five days, this indicator was steadily declining. On the $30^{\text {th }}$ day of lactation cases of forced milking by the operator were $24.3-35.9 \%$ and were the lowest in cows of German Holstein breed, indicating the best adaptive qualities of this cattle.

Table 2. Ethological signs of cow adaptations.

\begin{tabular}{|c|c|c|c|}
\hline Day & $\begin{array}{c}\text { Number of visits to feed } \\
\text { stations, times }\end{array}$ & $\begin{array}{l}\text { Number of passes through } \\
\text { selection gates, times } \\
\text { German Holstein }\end{array}$ & Forced milking cases, $\%$ \\
\hline 5 & $2.07 \pm 0.03$ & $5,18 \pm 0.02$ & 74.7 \\
\hline 10 & $2.61 \pm 0.04^{* * *}$ & $5.79 \pm 0.06^{* * *}$ & 63.1 \\
\hline 15 & $3.18 \pm 0.08^{* * *}$ & $6.08 \pm 0.09^{* *}$ & 59.9 \\
\hline 20 & $3.32 \pm 0.11$ & $6.34 \pm 0.08^{*}$ & 41.4 \\
\hline 25 & $3.39 \pm 0.08$ & $6.58 \pm 0.11$ & 38.7 \\
\hline \multirow[t]{2}{*}{30} & $3.52 \pm 0.06^{\# \# \#}$ & $6.64 \pm 0.14^{\# \# \#}$ & 24.3 \\
\hline & & French Holstein & \\
\hline 5 & $1.66 \pm 0.05$ & $4.31 \pm 0.07$ & 86.2 \\
\hline 10 & $1.89 \pm 0.04^{* * *}$ & $4.39 \pm 0.07$ & 73.4 \\
\hline 15 & $2.18 \pm 0.05^{* * *}$ & $4.70 \pm 0.10^{*}$ & 65.2 \\
\hline 20 & $2.24 \pm 0.09$ & $5.12 \pm 0.11^{* *}$ & 53.8 \\
\hline 25 & $2.56 \pm 0.06^{* *}$ & $5.37 \pm 0.07$ & 42.6 \\
\hline \multirow[t]{2}{*}{30} & $2.77 \pm 0.08^{*}$ & $5.72 \pm 0.09^{* *} ; \# \# \#$ & 33.7 \\
\hline & & Brown Swiss & \\
\hline 5 & $1.49 \pm 0.05$ & $4.17 \pm 0.06$ & 69.4 \\
\hline 10 & $1.75 \pm 0.08^{* *}$ & $4.48 \pm 0.06^{* * *}$ & 61.8 \\
\hline 15 & $2.06 \pm 0.04^{* * *}$ & $4.70 \pm 0.07^{*}$ & 53.6 \\
\hline 20 & $2.29 \pm 0.05^{* * *}$ & $4.89 \pm 0.05^{*}$ & 44.7 \\
\hline 25 & $2.46 \pm 0.04^{* *}$ & $5.22 \pm 0.07^{* * *}$ & 35.9 \\
\hline 30 & $2.59 \pm 0.06^{\# \# \#}$ & $5.39 \pm 0.08^{\# \# \#}$ & 28.4 \\
\hline
\end{tabular}

Notes: $* \mathrm{P}<0.05 ;{ }^{*} \mathrm{P}<0.01 ;{ }^{* * *} \mathrm{P}<0.001$ as compared to the previous period; ${ }^{\# \#} \mathrm{P}<0.001$ as compared to the first period (5 day).

The research results of leading scientists show increase in the content of somatic cells and electrical conductivity in cow's milk during stressful situations (Green et al., 2004; Feng et al., 2007; Bonnefort et al., 2011). Our studies show that the initial stay during voluntary milking was a stress factor for cows of all groups (Table 3). Subsequently, the content of somatic cells and the electrical conductivity of milk gradually decreased. The lowest rates were registered for German Holstein breed on the $30^{\text {th }}$ day: 207.4 thousand cells per $\mathrm{cm}^{3}$ and $4.72 \mathrm{mS} \mathrm{cm}^{-1}$ respectively. The number of somatic cells in cows of Swiss breed was 224.5 
thousand per $\mathrm{cm}^{3}$ and the electrical conductivity was $4.98 \mathrm{mS} \mathrm{cm}^{-1}$. The highest values of these indices were registered for French Holstein breed: 226.8 thousand per $\mathrm{cm}^{3}$ and $5.02 \mathrm{mS} \mathrm{cm}^{-1}$. These data indicate the worse adaptive properties of Brown Swiss breed and of French Holstein breed to the conditions of voluntary milking as compared to the German Holstein breed.

Table 3. Indicators of electrical conductivity and somatic cells content in the milk.

\begin{tabular}{ccc}
\hline Day & Electrical conductivity, $\mathbf{~ m S ~ c m}^{-1}$ & $\begin{array}{c}\text { Somatic cells content, thousand per cm } \\
\text { German Holstein }\end{array}$ \\
5 & $5.23 \pm 0.14$ & $238.7 \pm 6.11$ \\
10 & $5.17 \pm 0.05$ & $232.5 \pm 6.32$ \\
15 & $5.01 \pm 0.08$ & $221.4 \pm 4.37$ \\
20 & $4.83 \pm 0.11$ & $214.5 \pm 3.35$ \\
25 & $4.77 \pm 0.05$ & $211.1 \pm 4.23$ \\
30 & $4.72 \pm 0.09^{\# \#}$ & French Holstein \\
& & $207.4 \pm 4.02^{\# \# \#}$ \\
5 & $5.75 \pm 0.20$ & \\
10 & $5.64 \pm 0.12$ & $273.7 \pm 5.34$ \\
20 & $5.62 \pm 0.10$ & $265.5 \pm 7.61$ \\
25 & $5.30 \pm 0.09^{*}$ & $262.3 \pm 5.78$ \\
30 & $5.19 \pm 0.12$ & $243.6 \pm 8.37$ \\
5 & $5.02 \pm 0.15^{\# \#}$ & $235.3 \pm 6.44$ \\
10 & & $226.8 \pm 4.43^{\# \# \#}$ \\
15 & $5.86 \pm 0.07$ & \\
20 & $5.59 \pm 0.09^{*}$ & $280.9 \pm 8.19$ \\
25 & $5.52 \pm 0.12$ & $262.4 \pm 6.93$ \\
30 & $5.43 \pm 0.07$ & $259.8 \pm 7.58$ \\
\hline
\end{tabular}

Notes: See Table 2.

\section{Conclusion}

It was established that the German Holstein breed was distinguished by greater adaptation features as compared to the French breed and the Brown Swiss breed. During the adaptation period, the German Holstein breed was differed by higher milk yield, milking multiplicity and the amount of consumed concentrated feed in comparison with the French Holstein breed and Swissbreed. The German Holstein breed had lower electrical milk conductivity and the somatic cells amount in milk during the adaptation period in comparison with the French Holstein breed and Brown Swiss breed. So we suggested that the German Holstein breed had more higher stress resistance and thus less time-consuming adaptation to the keeping.

\section{References}

Bach, A. \& Cabrera, V. (2017). Robotic milking: Feeding strategies and economic returns. Journal of Dairy Science, 100, (9), 77207728. doi: 10.3168/jds.2016-11694

Bomko, V., Kropyvka, Yu., Bomko, L., Chernyuk, S., Kropyvka, S., Gutyj, B. (2018). Effect of mixed ligand complexes of Zinc, Manganese, and Cobalt on the Manganese balance in high-yielding cows during first 100-days lactation. Ukrainian Journal of Ecology, 8(1), 420-425. doi: 10.15421/2018_230

Bonnefont,C., Toufeer, M., Caubet, C., Foulon, E., Tasca, C., Aurel, M.R., Bergonier, D., Boullier, S., Robert-Granié, C., Foucras, G., \& Rupp, R. (2011). Transcriptomic analysis of milk somatic cells in mastitis resistant and susceptible sheep upon challenge with Staphylococcus epidermidis and Staphylococcus aureus. BMC Genomics 2011, 12:208. doi: 10.1186/1471-2164-12-208

Borshch, A.A., Borshch, A.V., Lutsenko, M.M., Merzlov, S.V., Kosior, L.T., Lastovska, I.A., \& Pirova, L.V. (2018). Amino acid and mineral composition of milk from local Ukrainian cows and their crossbreedings with Brown Swiss and Montbeliarde breeds. Journal of the Indonesian Tropical Animal Agriculture, 43 (3), 238-246. doi: 10.14710/jitaa.43.3.238-246

Borshch, O.O., Borshch, O.V., Donchenko, T.A., Kosior, L.T., \& Pirova, L.V. (2017) Influence of low temperatures on behavior, productivity and bioenergy parameters of dairy cows kept in cubicle stalls and deep litter system. Ukrainian Journal of Ecology, 7(3), 73-77. doi: 10.15421/2017_51

Córdova, H.A., Alessio, D.R., Cardozo, L.L., \& Neto, A.T. (2018). Impact of the factors of animal production and welfare on robotic milking frequency. Pesq. agropec. bras., Brasília, 53 (2),238-246. doi: 10.1590/s0100-204×2018000200013

Drach, U., Halachmi, I., Pnini, T., Izhaki, I., \& Degani, A. (2017). Automatic herding reduces labour and increases milking frequency in robotic milking. Biosystems Engineering, 155, 134-141. doi: 10.1016/j.biosystemseng.2016.12.010

Faly, L. I., Kolombar, T. M., Prokopenko, E. V., Pakhomov, O. Y., \& Brygadyrenko, V. V. (2017). Structure of litter macrofauna communities in poplar plantations in an urban ecosystem in Ukraine. Biosystems Diversity, 25(1), 29-38. doi: 10.15421/011705

Feng, S., Salter, A.M., Parr, T., \& Garnsworthy, P.C. (2007). Extraction and Quantitative Analysis of Stearoyl-Coenzyme A desaturase mRNA from Dairy Cow Milk Somatic Cells. Journal of Dairy Science, 90(9), 4128-4136. doi: 10.3168/jds.2006-830

Green, M.J., Burton, P.R., Green, L.E., Schukken,Y.H., Bradley, A.J., Peeler, E.J., \& Medley, G.F. (2004). The use of Markov chain Monte Carlo for analysis of correlated binary data: patterns of somatic cells in milk and the risk of clinical mastitis in dairy cows. Preventive Veterinary Medicine,64, (2-4), 157-174.

Gutyj, B., Grymak, Y., Drach, M., Bilyk, O., Matsjuk, O., Magrelo, N., Zmiya, M., \& Katsaraba, O. (2017). The impact of endogenous intoxication on biochemical indicators of blood of pregnant cows. Regulatory Mechanisms in Biosystems, 8(3), 438-443. doi: $10.15421 / 021768$

Hansen, B.G. (2015). Robotic milking-farmer experiences and adoption rate in Jæren, Norway. Journal of Rural Studies, 41, 109117. doi: $10.1016 /$ j.jrurstud.2015.08.004 
Holloway, L., \& Bear, C. (2019). Beyond resistance: geographies of divergent more-that-human coduct in robotic milking. Geoforum, 104, 212-221. doi: 10/1016/j.geoforum.2019.04.030

Holloway, L., Wilkinson, K., \& Bear, C. (2014). Robotic milking technologies and renegotiating situated ethical relationships on UK dairy farms. Agriculture and Human Values, 31(2), 185-199. doi: 10.1007/s10460-013-9473-3

Jacobs, J.A. \& Siegford, J.M. (2012). Lactating dairy cows adapt quickly to being milked by an automatic milking system. Journal of Dairy Science, 95, (3), 1575-1584. doi: 10.3168/jds.2011-4710

Kozak, V. M., \& Brygadyrenko, V. V. (2018). Impact of cadmium and lead on Megaphyllum kievense (Diplopoda, Julidae) in a laboratory experiment. Biosystems Diversity, 26(2), 128-131. doi: 10.15421/011820

Melin, M., Pettersson, G., Svennersten-Sjaunja, K., \& Wiktorsson, H. (2007). The effects of restricted feed access and social rank on feeding behavior, ruminating and intake for cows managed in automated milking systems. Applied Animal Behaviour Science, 107(1), 13-21. doi: 10.1016/j.applanim.2006.09.026

Munksgaard, L., Rushen, J., de Passillé, A.M., \& Krohn, C.C. (2011). Forced versus free traffic in an automated milking system. Livestock Science, 138, (1-3), 244-250. doi: 10.1016/j.livsci.2010.12.023

NRC. (2001). Nutrient Requirements of Dairy Cattle. 7th rev. ed. National. Academy Press, 2101 Constitution Avenue, N.W., Lockbox 285, Washington. 13-28.

Pérez-Ramírez, E., Peyraud, J.L., \& Delagarde, R. (2009). Restricting daily time at pasture at low and high pasture allowance: Effects on pasture intake and behavioral adaptation of lactating dairy cows. Journal of Dairy Science 92, (7), 3331-3340. doi: $10.3168 /$ jds.2008-1951

Rousing, T., Badsberg, J. H., Klaas, I. C., Hindhede, J., \& Sørensen, J. T. (2006). The association between fetching for milking and dairy cows' behaviour at milking, and avoidance of human approachdan on-farm study in herds with automatic milking systems. Livestock Science, 101(1), 219-227. doi: 10.1016/j.livprodsci.2005.11.013.

Shoshani, E. \& Chaffer, M. (2001). Robotic milking: a report of a field trial in israel Ezra Shoshani and Marcelo Chaffer. Proceedings of the Dutch-Israeli Seminar on Robotic Milking and Heat Stress, 41-50.

Sitkowska, B., Piwczyński, D., Aerts, J., \&Waśkowicz, M. (2015). Changes in milking parameters with robotic milking. Archive Animal Breeding, 58, 137-143. doi: 10.5194/aab-58-137-2015

Slivinska, L., Fedorovych, V., Gutyj, B., Lychuk, M., Shcherbatyy, A., Gudyma, T., Chernushkin, B., Fedorovych, N. (2018). The occurrence of osteodystrophy in cows with chronic micronutrients deficiency. Ukrainian Journal of Ecology, 8(2), 24-32. doi: 10.15421/2018_305

Slivinska, L., Shcherbatyy, A., Gutyj, B., Lychuk, M., Fedorovych, V., Maksymovych, I., Rusyn, V., Chernushkin, B. (2018). Parameters of erythrocytopoiesis, acid resistance and population composition of erythrocytes of cows with chronic hematuria. Ukrainian Journal of Ecology, 8(1), 379-385. doi: 10.15421/2017_225

Slivinska, L.G., Shcherbatyy, A.R., Lukashchuk, B.O., Zinko, H.O., Gutyj, B.V., Lychuk, M.G., Chernushkin, B.O., Leno, M.I., Prystupa, O.I., Leskiv, K.Y., Slepokura, O.I., Sobolev, O.I., Shkromada, O.I., Kysterna, O.S., Musiienko, O.V. (2019). Correction of indicators of erythrocytopoesis and microelement blood levels in cows under conditions of technogenic pollution. Ukrainian Journal of Ecology, 9(2), 127-135

Taylor, V.J., Beever, D.E., \& Wathes, D.C. (2004). Physiological Adaptations to Milk Production that Affect the Fertility of High Yielding Dairy Cows. BSAP Occasional Publication, 29, 37-71. doi: 10.1017/S0263967X00040040

\section{Citation:}

Borshch, O.O., Gutyj, B.V., Sobolev, O.I., Borshch, O.V., Ruban, S.Yu., Bilkevich, V.V., Dutka, V.R., Chernenko, O.M., Zhelavskyi, M.M., Nahirniak, T. (2020). Adaptation strategy of different cow genotypes to the voluntary milking system. Ukrainian Journal of Ecology, 10(1), 145-150. This work is licensed under a Creative Commons Attribution 4.0. License 